\title{
Benefits and Costs of International
}

\section{Financial Integration: Theory and Facts}

\author{
Pierre-Richard Agénor
}

\section{INTRODUCTION}

\begin{abstract}
$\mathfrak{T}$ HE degree of integration of financial markets around the world increased significantly during the late 1980s and 1990s. A key factor underlying this process has been the increased globalisation of investments seeking higher rates of return and the opportunity to diversify risk internationally. At the same time, many countries have encouraged inflows of capital by dismantling restrictions and controls on capital outflows, deregulating domestic financial markets, liberalising restrictions on foreign direct investment, and improving their economic environment and prospects through the introduction of market-oriented reforms. Indeed, many developing and transition economies in East Asia, Latin America, and Eastern Europe removed restrictions on international financial transactions, at the same time that they relaxed regulations on the operation of domestic financial markets and moving away from regimes of financial repression.

The increase in the degree of integration of world capital markets has been accompanied by a significant rise in private capital flows to developing countries. ${ }^{1}$ As shown in Figure 1, foreign direct investment to developing countries started growing in the 1980s and expanded at an accelerated rate after 1990, whereas
\end{abstract}

PIERRE-RICHARD AGÉNOR is from the World Bank, Washington DC. This paper was prepared for the conference on Financial Globalization: Issues and Challenges for Small States (Saint Kitts, 27-28 March, 2001), organised by the World Bank, the Malta Institute for Small States, and the Eastern Caribbean Central Bank. The author is grateful to various colleagues and participants at the conference, as well as an anonymous referee, for helpful discussions and comments. The views expressed in this paper are the author's own and do not necessarily represent those of the World Bank.

1 In addition to the growing trend toward integration of world capital markets and changes in policies and prospects in the recipient countries, global cyclical factors (such as the drop in shortterm interest rates in industrial countries in the early 1990s) also played an important role in explaining the surge in capital flows. See Agénor (2003, Ch. 7) for a review of the evidence on 'push' and 'pull' factors in the determination of the surge in capital flows during the 1990s. 
FIGURE 1

Net Flows of Investment to Developing Countries, 1970-2000 (in billions of US dollars)

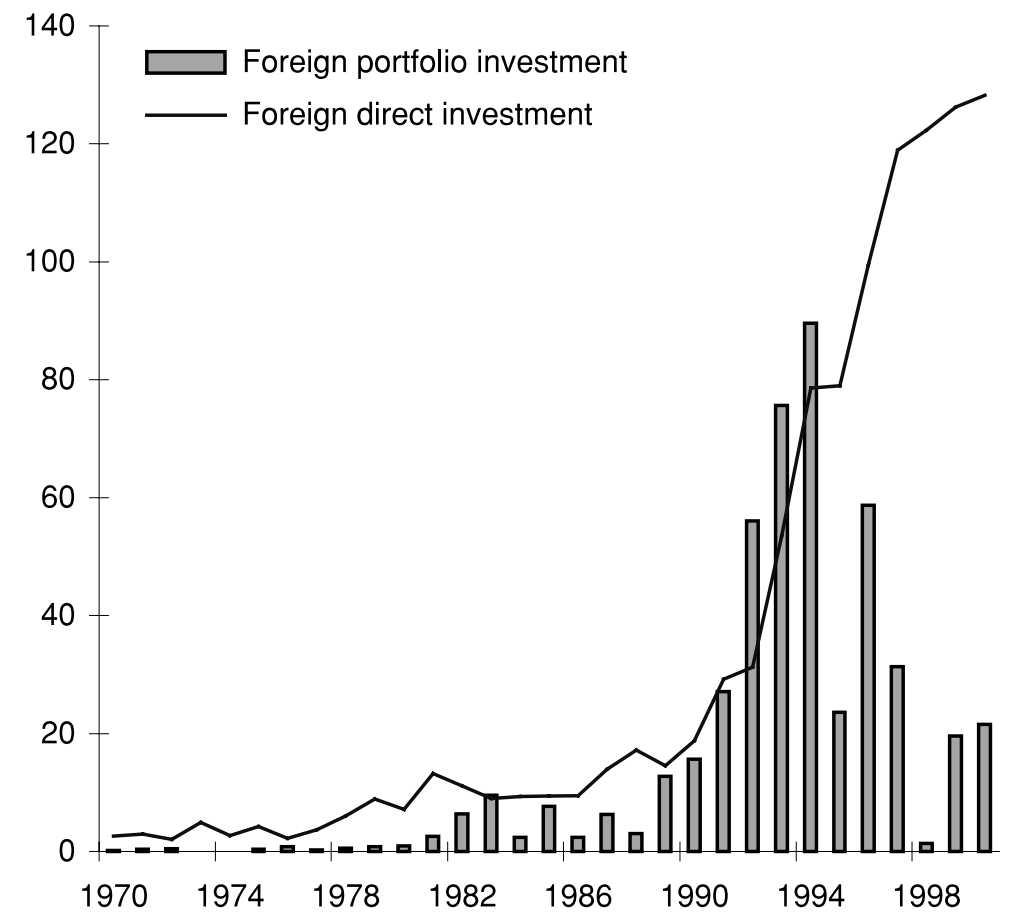

portfolio flows (which consist of equities, bonds and certificates of deposit) increased until the mid-1990s - reflecting, in effect, the increased incidence of financial volatility and currency crises in the last few years. At the same time, bank-intermediated flows fell significantly in proportion of total flows. Shortterm, cross-border capital flows have also become more responsive to changes in relative rates of return, as a result of technological advances and increased linkages among capital markets.

Financial openness is often regarded as providing important potential benefits. Access to world capital markets, as noted earlier, expands investors' opportunities for portfolio diversification and provides a potential for achieving higher risk-adjusted rates of return. From the point of view of the recipient country, there are potentially large benefits as well. It has been argued that access to world capital markets allows countries to borrow to smooth consumption in the face of adverse shocks, and that the potential growth and welfare gains resulting from such international risk sharing can be large and permanent (Obstfeld, 1994). At the same time, however, it has been recognised that the risk of volatility and abrupt reversals in capital flows in the context of a highly open capital account may represent a significant cost. Concerns associated with such reversals were 
heightened by a series of recent financial crises - including the Mexican peso crisis of December 1994, the Asian crisis of 1997, the Russian crisis of August 1998, the collapse of the Brazilian real in January 1999, the Turkish lira crisis of February 2001, and the Argentine peso crisis of December 2001-January 2002. Although misaligned fundamentals usually played a very important role in all of the above crises (in the form of either overvalued exchange rates, excessive short-term foreign borrowing, or growing fiscal and current account imbalances), they have called attention to the inherent instability of international financial markets and the risks that cross-border financial transactions can pose for countries with relatively fragile financial systems and weak regulatory and supervision structures.

In that perspective, a key issue has been to identify the policy prerequisites that may allow countries to exploit the gains, while minimising the risks, associated with financial openness. The purpose of this paper is to provide a selective review of the recent analytical and empirical literature on the benefits and costs of international financial integration, and to identify some key policy lessons for small open economies, particularly those that are pondering their options before embarking in programmes aimed at increasing financial openness. ${ }^{2}$ It is organised as follows. Section 2 reviews analytical arguments related to the benefits and costs of integration, with particular attention paid to the determinants of capital flows to small countries and the role of foreign bank penetration. Section 3 provides an assessment of the empirical evidence on the benefits and costs of financial integration, highlighting in the process areas in which this evidence appears to lack robustness. Section 4 discusses the role of the Tobin tax as an instrument to mitigate the volatility of speculative, short-term capital movements. Section 5 concludes and draws together some of the policy implications of the analysis.

\section{BENEFITS AND COSTS OF INTERNATIONAL FINANCIAL INTEGRATION: THEORY}

The benefits and costs of financial integration can be viewed either from the point of view of individual investors (such as, for instance, the opportunity for international risk diversification, as indicated earlier) or from the point of view of the countries initiating the process of integration. This paper focuses solely on the second perspective, ignoring in the process issues such as the homebias puzzle in the behaviour of private capital flows (see Obstfeld, 1998; and Stultz, 1999).

\footnotetext{
${ }^{2}$ See Yusuf (2001) for a recent discussion of other aspects of globalisation, such as trade and international public goods.
} 


\section{a. Potential Benefits}

Analytical arguments supporting financial openness (or, equivalently, an open capital account) revolve around four main considerations: the benefits of international risk sharing for consumption smoothing; the positive impact of capital flows on domestic investment and growth; enhanced macroeconomic discipline; and increased efficiency, as well as greater stability, of the domestic financial system associated with foreign bank penetration.

\section{(i) Consumption smoothing}

Access to world capital markets may allow a country to engage in risk sharing and consumption smoothing, by allowing the country to borrow in 'bad' times (say, during a recession or a sharp deterioration in the country's terms of trade) and lend in 'good' times (say, in an expansion or following an improvement in the country's terms of trade). By enabling domestic households to smooth their consumption path over time, capital flows can therefore increase welfare. This 'counter-cyclical' role of world capital markets is particularly important if shocks are temporary in nature.

\section{(ii) Domestic investment and growth}

The ability to draw upon the international pool of resources that financial openness gives access to may also affect domestic investment and growth. In many developing countries, the capacity to save is constrained by a low level of income. As long as the marginal return from investment is at least equal to the cost of (borrowed) capital, net foreign resource inflows can supplement domestic saving, increase levels of physical capital per worker, and help the recipient country raise its rate of economic growth and improve living standards. ${ }^{3}$ These potential benefits can be particularly large for some types of capital inflows, most notably foreign direct investment (FDI).

In addition to this direct effect on growth, FDI may also have significant indirect long-run effects. As emphasised early on by MacDougall (1960), and

\footnotetext{
${ }^{3}$ In general, foreign resource inflows can be viewed as an income transfer that can be either consumed or invested. In Obstfeld's (1999) model, for instance, a foreign resource inflow is no different from any other increase in income. Unless the rate of intertemporal substitution is very high, the representative agent will respond to a permanent resource inflow with an increase in consumption. Because the inflow affects income as well as consumption, saving may rise or fall. If the resource transfer is temporary or takes the form of a loan that must be repaid, the consumption effect is somewhat damped, but it is still likely to exceed the effect on investment. Thus, resource inflows may raise utility by allowing households to smooth consumption rather than by leading to a rise in investment and growth. However, it should be noted that utility-based models of this type may be deficient in some important ways. In particular, the assumption of a single representative agent assumes a degree of capital market development - equalisation of lending and borrowing rates - that does not exist in most developing countries.
} 
more recently by Berthélemy and Démurger (2000), Borensztein, De Gregorio and Lee (1998), and Grossman and Helpman (1991), FDI may facilitate the transfer or diffusion of managerial and technological know-how - particularly in the form of new varieties of capital inputs - and improve the skills composition of the labour force as a result of 'learning by doing' effects, investment in formal education, and on-the-job training. In addition, as suggested by Markusen and Venables (1999), although the increased degree of competition in the product and factor markets induced by FDI may tend to reduce profits of local firms, spillover effects through linkages to supplier industries may reduce input costs, raise profits and stimulate domestic investment.

To highlight the complementarity (through productivity effects) between FDI and skilled human capital in the growth process consider, following Borensztein, De Gregorio and Lee (1998), an economy in which the source of technological progress is an increase in the number of varieties of capital goods available to producers, which consist of local and foreign firms. Suppose also that the economy produces a single final consumption good using the following technology:

$$
Y=S^{\alpha} K^{1-\alpha}
$$

where $0<\alpha<1$ and $S$ is the economy's endowment of skilled labour (assumed given) and $K$ is the stock of physical capital, which is itself a composite of a continuum of different varieties of capital goods, each one denoted by $x(j)$ :

$$
K=\int_{0}^{N}\left[x(j)^{1-\alpha} \mathrm{d} j\right]^{1 /(1-\alpha)},
$$

with $N$ denoting the total number of varieties. Physical capital accumulation therefore takes place through an increase in the number of varieties of capital goods produced domestically.

Suppose that there are two types of firms producing capital goods: foreign firms, which produce $n^{*}<N$ varieties, and domestic firms, which produce the other $N-n^{*}$ varieties. Specialised firms produce each variety $j$ of capital goods and rent it out to producers of final goods at a rate $m(j)$. The optimal demand for each variety $j$ is thus determined by equating the rental rate and the marginal productivity of $j$ in the production of the final good:

$$
m(j)=(1-\alpha) S^{\alpha} x(j)^{-\alpha}
$$

An increase in the number of varieties of capital goods available to producers is assumed to require the adaptation of technology available in more advanced countries. This adaptation to local needs requires a fixed setup cost, $F$, which is assumed to depend negatively on the ratio of foreign firms operating domestically 
to the total number of firms, $n^{*} / N$. Thus, $F=F\left(n^{*} / N\right)$, with $F^{\prime}<0 .{ }^{4}$ This assumption captures the idea that foreign firms make it easier to adopt the more advanced technology required to produce new varieties of capital, by bringing in the 'knowledge' already available elsewhere.

In addition to this fixed cost, once a capital good is introduced, its owner must spend a constant maintenance cost per period of time. This is equivalent to assuming that production of $x(j)$ involves a constant marginal cost equal to unity and that capital goods depreciate fully. Assuming that the interest rate $r$ that firms face is constant, profits for the producer of a variety $j$, denoted $\Pi(j)$, are given by:

$$
\Pi(j)=-F+\int_{0}^{N}[m(j) x(j)-x(j)] e^{-r s} \mathrm{~d} s .
$$

Maximisation of (2) subject to (1) yields the equilibrium level of production of each capital good:

$$
x(j)=S(1-\alpha)^{2 / \alpha},
$$

which shows that, given the assumption of symmetry among producers, the level of production of the different varieties of capital is the same. ${ }^{5}$ Assuming free entry, it can be shown that the zero-profit condition implies that

$$
r=\phi S / F
$$

where $\phi \equiv \alpha(1-\alpha)^{(2-\alpha) / \alpha}>0$.

To close the model requires specifying savings decisions, which determine the process of capital accumulation. Suppose that households face a rate of return also equal to $r$ and that they maximise a standard intertemporal utility function given by the discounted present value of consumption. It can be shown (see, e.g., Barro and Sala-i-Martin, 1995) that the optimal solution for the rate of growth of consumption, $g_{c}$, is:

$$
g_{c}=(r-\rho) / \sigma
$$

where $\rho$ is the rate of time preference and $1 / \sigma$ measures the intertemporal elasticity of substitution. In a stationary state, the rate of growth of consumption must

\footnotetext{
${ }^{4}$ Borensztein, De Gregorio and Lee (1998) also discuss a second possible effect on $F$, namely, the possibility of a 'catch-up' effect in technological progress reflecting the fact that it may be cheaper to imitate products already in existence than to create new ones at the cutting edge of innovation. This notion is implemented in their model by assuming that setup costs depend positively on the number of capital varieties produced domestically, compared to those produced abroad.

${ }^{5}$ Substituting the optimal level of production into equation (1) yields the constant equilibrium rental rate, $m(j)=1 /(1-\alpha)$, as a markup over maintenance costs.
} 
be equal to the rate of growth of output, $g$. Substituting (3) in (4) yields therefore the economy's growth rate:

$$
g=\left[\phi S / F\left(n^{*} / N\right)-\rho\right] / \sigma .
$$

Equation (5) shows that FDI, as measured by the fraction of capital goods produced locally by foreign firms in the total number of these goods, $n^{*} / N$, has a positive effect on the economy's long-term growth rate. The reason is that FDI reduces the cost of introducing new varieties of capital, thereby increasing the rate at which these goods are introduced. ${ }^{6}$ Moreover, the effect of FDI on the economy's growth rate is positively related to the existing stock of skilled labour employed in production - this is the complementarity effect mentioned earlier.

Another channel through which international financial integration may affect positively the rate of economic growth is through its effect on total factor productivity. Levine (2000) has argued that, in principle, the liberalisation of international portfolio capital flows may lead to higher rates of economic growth because it may tend to accelerate the development of domestic equity markets and that, in turn, may lead to increased factor productivity. ${ }^{7}$

\section{(iii) Enhanced macroeconomic discipline}

It has also been argued that by increasing the rewards of good policies and the penalties for bad policies, the free flow of capital across borders may induce countries to follow more disciplined macroeconomic policies and thus reduce the frequency of policy mistakes (Obstfeld, 1998). To the extent that greater policy discipline translates into greater macroeconomic stability, it may also lead to higher rates of economic growth, as emphasised in the recent literature on endogenous growth. A related argument is that external financial liberalisation can act as a 'signal' that a country is willing (or ready to) adopt 'sound' macroeconomic policies, for instance by reducing budget deficits and forgoing the use of the inflation tax (Bartolini and Drazen, 1997). From that perspective, an open capital account may also encourage macroeconomic and financial stability, ensuring a more efficient allocation of resources and higher rates of economic growth.

\section{(iv) Increased banking system efficiency and financial stability}

An increasingly common argument in favour of financial openness is that it may increase the depth and breadth of domestic financial markets and lead to an

\footnotetext{
${ }^{6}$ In addition to reducing costs associated with innovation activity, FDI can also have a more direct effect on growth - if, for instance, local firms involved in research activities are able to use at least in part the advanced knowledge that foreign firms possess. As discussed by Berthélemy and Démurger (2000), it would then be the number of varieties of capital goods, and not the rate of change of the capital stock, that would affect long-run growth.

7 A similar effect may be associated with a higher degree of penetration of foreign banks in domestic financial markets, as discussed below.
} 
increase in the degree of efficiency of the financial intermediation process, by lowering costs and 'excessive' profits associated with monopolistic or cartelised markets. In turn, improved efficiency may lead to lower markup rates in banking, a lower cost of investment and higher growth rates (Baldwin and Forslid, 2000). ${ }^{8}$ More generally, Levine (1996) and Caprio and Honohan (1999) have argued that foreign bank penetration may:

- improve the quality and availability of financial services in the domestic market, by increasing the degree of bank competition and enabling the application of more sophisticated banking techniques and technology (such as more advanced risk management systems), which may improve efficiency by reducing the cost of acquiring and processing information on potential borrowers;

- serve to stimulate the development of the domestic bank supervisory and legal framework, if the local foreign banks are supervised on a consolidated basis with their parent;

- enhance a country's access to international capital, either directly or indirectly through parent banks;

- contribute to the stability of the domestic financial system (and reduced volatility in capital flows) if, in periods of financial instability, depositors may shift their funds to foreign institutions that are perceived to be more sound than domestically-owned banks, rather than transferring assets abroad through capital flight.

In addition, foreign banks may also contribute to an improvement in the overall quality of the loan portfolios of domestic banks if they are less susceptible to government pressure to lend to 'preferred' borrowers - as may be the case with domestic financial institutions, particularly those in which the state is involved.

\section{b. Potential Costs}

The experience of the past two decades has led economists and policymakers to recognise that, in addition to the potential benefits just discussed, open financial markets may also generate significant costs. These costs include a high degree of concentration of capital flows and lack of access to financing for small countries, either permanently or when they need it most; an inadequate domestic allocation of these flows, which may hamper their growth effects and exacerbate preexisting domestic distortions; the loss of macroeconomic stability; pro-cyclical movements in short-term capital flows; a high degree of volatility of capital flows, which relates in part to herding and contagion effects; and risks associated with foreign bank penetration.

\footnotetext{
${ }^{8}$ Indeed, the need to improve banking sector efficiency in order to reduce the cost of financial intermediation and promote investment is a key policy objective in many developing countries.
} 


\section{(i) Concentration of capital flows and lack of access}

There is ample historical evidence to suggest that periods of 'surge' in crossborder capital flows tend to be highly concentrated to a small number of recipient countries. The dramatic increase in capital inflows in the early 1990s, for instance, was directed to only a small number of large, middle-income countries of Latin America and Asia (see Fernandez-Arias and Montiel, 1996). The share of total private capital flows going to low-income countries actually fell during the 1990s (from levels that were already quite low), whereas the share going to the top ten recipients increased significantly (see World Bank, 2001a). Little foreign capital is directed at sub-Saharan African countries, and most of what flows to the region is limited to a few countries (such as Angola, Nigeria and South Africa) with significant natural resources (see Bhattacharya, Montiel and Sharma, 1997; and Basu and Srinivasan, 2002). ${ }^{9}$ Thus, a number of developing countries (particularly the small ones) may simply be 'rationed out' of world capital markets - regardless of how open their capital account is.

\section{(ii) Domestic misallocation of capital flows}

Although the inflows of capital associated with an open capital account may raise domestic investment, their impact on long-run growth may be limited (if not negligible) if such inflows are used to finance speculative or low-quality domestic investments - such as investments in the real estate sector. Low-productivity investments in the non-tradables sector may reduce over time the economy's capacity to export and lead to growing external imbalances.

The misallocation of capital inflows may in part be the result of pre-existing distortions in the domestic financial system. In countries with weak banks (that is, banks with low or negative net worth and a low ratio of capital to risk-adjusted assets) and poor supervision of the financial system, the direct or indirect intermediation of large amounts of funds by the banking system may exacerbate the moral hazard problems associated with (explicit or implicit) deposit insurance. That is, lenders may engage in riskier and more concentrated (or outright speculative) loan operations.

An example of how asymmetric information problems can affect the benefits of capital inflows is provided by Razin, Sadka and Yuen (1999), who focus on the impact of FDI flows. They argue that through FDI and the transfer of control that it entails, foreign investors may gain inside information about the productivity of the firm(s) that they are investing in. This gives them an informational advantage over less informed domestic investors (whose holdings of

\footnotetext{
${ }^{9}$ At the same time, however, it should be noted that although many countries received a relatively small fraction of flows in absolute terms, several of them received sizeable inflows in relative terms (that is, adjusting for country size). This was the case for several small countries in Latin America (such as Costa Rica) and sub-Saharan Africa (such as Lesotho and Namibia).
} 
shares may be insufficient to give them corporate control) - an advantage that they may be tempted to exploit by retaining the high-productivity firms and selling the low-productivity ones to partially-informed domestic savers. This type of adverse selection problem can lead to over-investment by foreign direct investors.

\section{(iii) Loss of macroeconomic stability}

The large capital inflows induced by financial openness can have undesirable macroeconomic effects, including rapid monetary expansion (due to the difficulty and cost of pursuing sterilisation policies), inflationary pressures (resulting from the effect of capital inflows on domestic spending), real exchange rate appreciation and widening current account deficits. Under a flexible exchange rate, growing external deficits tend to bring about a currency depreciation, which may eventually lead to a realignment of relative prices and induce self-correcting movements in trade flows. By contrast, under a fixed exchange rate regime, losses in competitiveness and growing external imbalances can erode confidence in the viability and sustainability of the peg, thereby precipitating a currency crisis and increasing financial instability.

\section{(iv) Pro-cyclicality of short-term flows}

As noted earlier, small developing economies are often rationed out of world capital markets. Moreover, among those countries with a greater potential to access these markets (such as oil producers), the availability of resources may be asymmetric. These countries may indeed be able to borrow only in 'good' times, whereas in 'bad' times they tend to face credit constraints. Access may thus be pro-cyclical. Clearly, in such conditions, one of the alleged benefits of accessing world capital markets, the ability to borrow to smooth consumption in the face of temporary adverse shocks, is simply a fiction. Pro-cyclicality may, in fact, have a perverse effect and increase macroeconomic instability: favourable shocks may attract large capital inflows and encourage consumption and spending at levels that are unsustainable in the longer term, forcing countries to over-adjust when an adverse shock hits.

There are essentially two reasons that may explain the pro-cyclical behaviour of short-term capital flows. First, economic shocks tend to be larger and more frequent in developing countries, reflecting these countries' relatively narrow production base and greater dependence on primary commodity exports. A common adverse shock to a group of countries may cause a deterioration in some countries' creditworthiness, as a result of abrupt changes in risk perception. This can lead borrowers who are only marginally creditworthy to be 'squeezed out' of world capital markets. Dadush, Dasgupta and Ratha (2000) found indeed evidence of a non-linear relationship between a measure of creditors' risk perception and economic shocks in developing countries; perceived risk appears 
to increase more during a large adverse shock than it declines during a small adverse or a positive shock. Second, asymmetric information problems may trigger herding behaviour (as further discussed below) because partiallyinformed investors may rush to withdraw 'en masse' their capital in response to an adverse shock whose economic consequences for the country are not fully understood.

\section{(v) Herding, contagion and volatility of capital flows}

A high degree of financial openness may be conducive to a high degree of volatility in capital movements, a specific manifestation of which being large reversals in short-term flows associated with speculative pressures on the domestic currency. The possibility of large reversals of short-term capital flows raises the risk that borrowers may face costly 'liquidity runs', as discussed for instance by Chang and Velasco (2000). The higher the level of short-term debt is relative to the borrowing country's international reserves, the greater the risk of such runs will be. High levels of short-term liabilities intermediated by the financial system also create risks of bank runs and systemic financial crises.

In general, the degree of volatility of capital flows is related to both actual and perceived movements in domestic economic fundamentals, as well as external factors, such as movements in world interest rates. ${ }^{10}$ More generally, the fact that investor sentiment (particularly that of highly leveraged, speculative trading institutions, such as hedge funds) is constantly changing in response to new information creates the potential for markets to overshoot on a scale that can generate financial crises with very large economic and social costs. Short-term portfolio flows, in particular, tend to be very sensitive to herding among investors and contagious factors. Although investor herding is seen by some as evidence of irrationality, some recent literature suggests differently. Herding can be a 'rational' response in the presence of several effects:

- payoff externalities, which are related to the fact that the payoff to an agent (investor) adopting a specific action may be positively related to the number of other agents adopting the same action;

- principal-agent considerations, which result from the fact that a portfolio manager, in order to maintain or improve his or her reputation when markets are imperfectly informed, may prefer either to 'hide in the herd' to avoid evaluation and criticism, or to 'ride the herd' to generate reputational gains;

- information cascades, which are due to the fact that (small) agents that are only beginning to invest in a country may find it optimal to ignore their

${ }^{10}$ Volatility can also be magnified by domestic market distortions. To the extent that private capital flows are channelled to the domestic economy through commercial banks, credit market inefficiencies can magnify the effect of changes in, say, external interest rates, and lead to fluctuations in domestic output that may have feedback effects on capital flows (see Agénor and Aizenman, 1999). 
own information and follow the behaviour of larger and more established investors. ${ }^{11}$

In any case, rational or irrational, herding behaviour often translates into large movements into and out of certain types of assets and exacerbates fluctuations in asset prices and capital movements.

Volatility of capital flows can also result from contagion effects. Financial contagion may occur when a country suffers massive capital outflows triggered by a perceived increase by international investors in the vulnerability of a country's currency, or, more generally, a loss of confidence in the country's economic prospects, as a result of developments elsewhere (see Dornbusch, Park and Claessens, 2000; and Masson, 2000). It may also occur through two other channels, with indirect effects on the volatility of capital flows: terms-of-trade shocks or competitiveness effects. An example of the former effect is provided by the events that followed the Asia crisis, which led to a sharp reduction in the demand for imports by crisis-stricken countries and a sharp drop in world commodity prices. By increasing the degree of uncertainty regarding the short-term economic prospects of a country, terms-of-trade shocks may translate into financial contagion - as appeared to have happened in the case of Chile in late 1997 and early 1998. As an example of the latter effect, the sharp depreciation of the Thai baht that began in July 1997 put pressure on the currencies of neighbouring countries that maintained a pegged exchange rate, in part because it implied a large loss of competitiveness for these countries (see Alba et al., 1999).

(vi) Risk of entry by foreign banks

Although foreign bank penetration can yield several types of benefits (as discussed earlier), it also has some potential drawbacks as well. First, foreign banks may ration credit to small firms (which tend to operate in the non-tradables sector) to a larger extent than domestic banks, and concentrate instead on larger and stronger ones (which are often involved in the production of tradables). If foreign banks do indeed follow a strategy of concentrating their lending operations only to the most creditworthy corporate (and, to a lesser extent, household) borrowers, their presence will be less likely to contribute to an overall increase in efficiency in the financial sector. More importantly, by leading to a

11 Consider, for instance, the model of Calvo and Mendoza (1997), which assumes a global market
with many identical investors forming decisions simultaneously. Investors determine (for given means
and variances of asset returns) the optimal trade-off between diversification and costly-information
collection. With informational frictions, rational herding behaviour may become more prevalent as
the world capital market grows. The reason is that financial integration reduces the incentives to
collect country-specific information to discredit rumours and increases the likelihood that fund
managers who worry about their relative performance will each select the same portfolio. Conse-
quently, small rumours can induce herding behaviour and lead to large capital outflows (seemingly
unrelated with a country's economic fundamentals) and a self-fulfilling speculative currency attack. 
higher degree of credit rationing to small firms, they may have an adverse effect on output, employment and income distribution.

Second, entry of foreign banks, which tend to have lower operational costs, can create pressures on local banks to merge in order to remain competitive. The process of concentration (which could also arise as foreign banks acquire local banks) could create banks that are 'too big to fail' or 'too political to fail' - as monetary authorities may fear that the failure of a single large bank could seriously disrupt financial markets and lead to social disruptions. Although these potential problems could be mitigated through enhanced prudential supervision or an outright ban on mergers that are perceived to increase systemic risks sharply, they may lead to an undesirable extension of the scope and cost of the official safety net. A too-big-to-fail problem may, in turn, increase moral hazard problems: knowing the existence of an (implicit) safety net, domestic banks (particularly those in which the state is involved) may be less careful in allocating credit and screening potential borrowers. Concentration could also create monopoly power that would reduce the overall efficiency of the banking system and the availability of credit. In particular, a high degree of banking system concentration may adversely affect output and growth by yielding both higher interest rate spreads (with higher loan rates and lower deposit rates relative to competitive credit and deposit markets) and a lower amount of loans than in a less concentrated, more competitive system.

Third, entry of foreign banks may not lead to enhanced stability of the domestic banking system, because their presence per se does not make systemic banking crises less likely to occur - as may happen if the economy undergoes a severe and persistent recession, leading to a large increase in default rates and a rise in non-performing loans, and because they may have a tendency to 'cut and run' during a crisis. ${ }^{12}$ To some extent, the latter effect could again be mitigated by strengthening prudential supervision in domestic markets, and improving information sharing between supervisors in industrial and receiving countries. In practice, however, countries have very few options to prevent foreign banks from, say, cutting lines of credit to domestic borrowers in a crisis.

\section{WHAT IS THE EVIDENCE?}

The foregoing discussion suggests that, from a purely analytical point of view, it cannot be established a priori whether the benefits of financial openness are

\footnotetext{
${ }^{12}$ Some observers have argued that the fact that foreign banks may withdraw abruptly after a period of time if they fail to establish profitable operations is also a potential drawback associated with foreign bank entry. However, the issue is the context in which a foreign bank is withdrawing (whether it is during a crisis or not), not the fact that it chooses to close its doors because it is unable to make profits (which, in itself, may actually be a desirable outcome).
} 
likely to outweigh its potential costs. This section examines the empirical evidence on the various costs and benefits identified earlier in order to determine if, on balance, unambiguous conclusions can be offered. At the outset, it is important to note that the task is far from being straightforward, although some of the historical evidence for smaller industrial countries appears to suggest substantial net benefits. ${ }^{13}$ The reason is that to quantify the gains countries can reap from international financial integration would require, to be rigorous, a fully articulated model in which the counterfactual of financial autarky could be simulated. So far there has been no such ambitious attempt. Nevertheless, a selective review of the evidence, both formal (econometric) and informal (country experiences), is provided here, beginning with a review of the determinants of the volatility and pro-cyclicality of capital flows, and continuing with the impact of the degree of financial openness and capital flows on domestic investment and growth; the macroeconomic effects of large capital inflows (dwelling mostly on the experience of the early 1990s); and the effect of foreign bank entry on the performance and stability of the domestic financial system. ${ }^{14}$

\section{a. Volatility and Pro-cyclicality of Capital Flows}

As discussed earlier, it has been argued that short-term capital flows tend to be more unstable than longer-term flows, and thus more conducive to financial crises. Several studies have attempted to examine the degree of volatility (or, conversely, persistence) of cross-border capital flows during the past two decades. In one of the early studies on this topic, Claessens, Dooley and Warner (1995) were unable to detect significant differences in the volatility patterns of FDI, portfolio equity, long-term debt and short-term debt flows. Several subsequent studies, however, have reached different conclusions; most of them have found that FDI tends to be less volatile than other forms of capital flows. Chuhan, Perez-Quiros and Popper (1996), for instance, found that short-term capital flows respond more dramatically to financial disturbances than FDI flows. Another recent study by Brewer and Nollen (2000) of 17 developing countries that were major recipients of FDI during the past two decades yielded similar results. On the basis of annual data for FDI flows and total portfolio flows for the period 1985-94, they found that in 11 of the 13 countries for which comparisons could be made, the coefficient of variation was greater for portfolio flows than for FDI flows. Finally,

\footnotetext{
${ }^{13}$ See Obstfeld (1998). The evidence gathered by Lewis (1996) also suggests that, historically, economies with closed capital accounts have tended to experience a higher degree of volatility of domestic consumption.

${ }^{14} \mathrm{I}$ abstract in what follows from discussing empirical studies of the indirect effect of international financial integration (namely, the liberalisation of portfolio investment rules) on domestic stock market development, factor productivity and growth. See, in particular, Levine (2000) and the World Bank (2001b, pp. 169-78).
} 
Sarno and Taylor (1999), using a decomposition of various types of capital flows into permanent (trend) and transitory (cyclical) components, found that FDI has a higher permanent component than other flows. ${ }^{15}$

There is also evidence that short-term capital flows to developing countries appear to be pro-cyclical. A recent World Bank study, for instance, based on data for 33 developing countries during 1986-98, found that such flows tend to increase when economic growth is cyclically faster and decline when growth rates fall (Dadush, Dasgupta and Ratha, 2000). ${ }^{16}$ In contrast, medium- and long-term capital flows appeared to be weakly counter-cyclical to GDP shocks. By itself, this pro-cyclical behaviour may not be a cause for concern if it results from changes in demand in the developing countries themselves. In practice, however, it often arises from external, supply-side factors, such as a sudden change in the country's terms of trade, which raises the risk perceptions of lenders; it tends therefore to magnify the impact of a shock. Indeed, the same study found the pro-cyclical response to be twice as large when a country faces an adverse terms-of-trade shock relative to when it faces a positive shock.

At a less formal level, the experience with financial crises during the past few years indicates that many countries suffered large reversals in short-term capital flows. For instance, in the wake of the Asia crisis, although FDI remained remarkably stable, short-term capital inflows from BIS-reporting banks to developing countries fell from $\$ 43.5$ billion in 1997 to $\$ 85$ billion in 1998 (Dadush, Dasgupta and Ratha, 2000). ${ }^{17}$ Volatility in capital inflows has also tended to translate into exchange rate instability (under flexible exchange rates) or large fluctuations in official reserves (under a pegged exchange rate regime), and greater volatility in domestic equity markets. Financial volatility may have led to adverse real effects as well - nominal exchange rate volatility, in particular, may hamper

\footnotetext{
15 The finding that FDI flows tend to be more stable than other types of flows should be taken, however, with some degree of caution. First, because FDI as conventionally measured includes the retained earnings of all previous FDI flows, it tends to display more inertia. Second, the classification of direct and portfolio flows in balance-of-payments statistics is somewhat arbitrary. Foreign investment in the equity of a company above a critical proportion (say, ten per cent) of outstanding equity is usually classified as FDI, whereas that below the critical threshold is classified as portfolio investment. However, small differences above or below the threshold do not necessarily represent any significant difference in the intentions of investors.

${ }^{16}$ The study found that the elasticity of short-term debt with respect to GDP was about 0.9 when GDP growth experiences a positive shock (defined as a rate of growth that is one-half standard deviation or more above the mean growth rate), but 1.8 when an adverse shock occurs (that is, when GDP growth is one-half standard deviation or more below the mean). In other words, the rate of decline of short-term debt during an adverse shock was twice as high as its rate of increase during a positive shock.

${ }^{17}$ It should be noted that, in practice, 'FDI reversals' can also occur, even though physical capital (such as buildings and heavy equipment) cannot be easily moved out of a country at short notice. Such reversals can be accomplished through financial transactions. For instance, the foreign subsidiary in the host country can borrow domestically against its local assets and then transfer (lend) the funds to its parent company abroad.
} 
the expansion of exports if appropriate hedging techniques are not available to domestic producers.

\section{b. Impact on Investment and Growth}

Studies examining the impact of international financial integration on domestic investment and growth can be classified in two groups. The first group attempts to measure directly the impact of capital account liberalisation by exploiting qualitative information on restrictions on capital movements, whereas the second uses the level of capital flows as a proxy measure for the degree of financial openness. There are significant differences between these two approaches.

Two recent studies focusing directly on the impact of capital account liberalisation on growth are those of Klein and Olivei (2001) and Artera, Eichengreen and Wyplosz (2001). In both studies the degree of capital account liberalisation is measured by an index of capital account restrictions, calculated using IMF data on exchange rate arrangements and exchange restrictions. Klein and Olivei (2001) analysed the effects of capital account liberalisation on growth and financial depth for a cross-section of countries over the period 1986-95. They found that countries with open capital accounts experienced a larger increase in financial depth than countries with closed capital accounts, and through that channel, higher rates of economic growth. However, this positive effect appears to be significant only for industrial countries, not for developing countries. The second study found some evidence of a positive link between the index of capital account openness and growth, but only when countries are already sufficiently open commercially and face limited macroeconomic imbalances. This is an important result because it brings to the fore the issue of sequencing of reforms.

The second group of studies is based on the view that actual levels of capital movements provide a good proxy for the effective degree of financial openness. It includes those of Agosin and Mayer (2000), Bosworth and Collins (2000), Blomstrom, Lipsey and Zejan (1994), Borensztein, De Gregorio and Lee (1998), Gruben and McLeod (1998), Carkovic and Levine (2002) and Edison, Levine, Ricci and Slok (2002). Agosin and Mayer (2000), using panel data for 32 countries for the period 1970-96, found that FDI had a 'crowding in' effect on private domestic investment in Asia and to a lesser extent in Africa; by contrast, FDI had a strong 'crowding out' effect on domestic capital formation in Latin America. Bosworth and Collins (2000) used panel regression techniques to evaluate the impact of capital inflows on investment for a group of 58 developing countries during the period 1978-95. They found that FDI flows have a positive (and almost one-for-one) impact on investment, whereas portfolio flows have no discernible effect. Kumar and Pradhan (2001), in a study of 55 poor countries during the period 1980-99, found that a one per cent rise in the ratio of FDI to GDP was associated with an increase in GDP growth of about 0.18 per cent in 
these countries, compared with a rise of 0.12 per cent in the case of domestic investment. By contrast, Blomstrom, Lipsey and Zejan (1994) found that the impact of FDI on growth in lower-income countries, although positive, was not statistically significant. Borensztein, De Gregorio and Lee (1998), using FDI flows from industrial countries to 69 developing countries during the period 1970-89, found that the link between FDI and growth was positive and significant. A similar result was obtained by Gruben and McLeod (1998). Moreover, Borensztein, De Gregorio and Lee also found that there is complementarity between FDI and human capital (proxied by a measure of educational attainment) in affecting growth, as hypothesised in the growth model highlighted earlier, and that FDI has a positive (although not very robust) impact on aggregate domestic investment.

Thus, to the extent that the size of capital flows (particularly in the form of FDI) can be seen as an adequate proxy for the degree of financial openness, the above studies suggest that financial integration has a positive effect on domestic investment and growth. However, some caution is needed in making that claim. First, the foregoing discussion relied on the assumption that greater financial openness translates into larger capital inflows. There is indeed evidence supporting this contention, at least on average and over a sufficient period of time. As a result, using the size of capital inflows as a proxy for the degree of financial integration is a sensible approach when the focus is on longer-term movements in investment and growth, given also the practical difficulties involved in constructing a quantitative index of financial openness. However, the relation between the degree of capital account openness and capital inflows is not always very close, particularly in the short term; a country can experience periods of low inflows (as a result, say, of a change in market sentiment), regardless of how open its capital account is. This raises the issue of understanding and identifying both the shortand long-term determinants of capital flows themselves. There is by now a sizeable literature, most of it reviewed in Agénor (2003, Ch. 7), focusing on the determinants of private capital flows during the 1990s and distinguishing between 'push' (or external) and 'pull' (or domestic) factors. The evidence suggests that the relationship between financial integration (as proxied by the size of FDI flows) and growth may be bi-directional: capital inflows may have a positive effect on growth, but growth in turn may tend to stimulate the inflow of FDI. This is an important result because it highlights the possibility of a "virtuous circle' between capital flows and growth-enhancing policies. It also implies that studies of the impact of FDI on growth that do not account for the endogenous nature of capital flows (that is, the fact that FDI can be itself influenced by the economy's growth rate) are likely to produce estimated coefficients that are subject to significant bias. Several of the above-cited studies do not account for this problem. Two of the most recent studies, by Carkovic and Levine (2002), and Edison, Levine, Ricci and Slok (2002), do account for it, as well as a host of other potential econometric problems. Using advanced panel data econometric 
techniques, these authors failed to find a robust, independent effect of FDI and various other measures of international financial openness on growth.

Second, it is important to account for microeconomic evidence on the effects of FDI. This evidence, which is discussed by Eichengreen (2001) and the World Bank (2001a), suggests that private capital flows may enhance productivity, particularly in countries with a relatively skilled labour force and a well-developed physical infrastructure. Haddad and Harrison (1993), for instance, in a study of the impact of foreign investment on firms in Morocco's manufacturing sector during the period 1985-89, found that although domestic firms exhibit lower levels of total factor productivity, their rate of productivity growth is higher than that for foreign firms. Moreover, domestic firms exhibit higher levels of productivity in sectors with a larger foreign presence. ${ }^{18}$ At the same time, however, there is some evidence suggesting that domestic firms may not be able to capitalise on the transfer of knowledge associated with FDI because the entry of foreign firms may lead to losses in market share and reduced productivity, as a result of a contraction in output (Aitken and Harrison, 1999). More generally, microeconomic evidence is important in judging the impact of capital flows on the quality of domestic investment. Indeed, one lesson from the Asia crisis is that high, aggregate ratios of capital formation to GDP can mask a sharp decline in the productivity of these investments.

Third, it should be noted that most of the econometric studies referred to above do not test for the existence of an adverse effect of the volatility of capital flows (as opposed to their level) on investment and growth. As the literature on uncertainty and irreversibility in investment decisions has emphasised (see, for instance, Dixit and Pindyck, 1994), uncertainty about the availability of external finance in the future may deter investment, particularly in projects that have long gestation periods. Some preliminary evidence by the World Bank (2001a) suggests indeed that the volatility of private capital flows (as measured by the standard deviation of these flows) has indeed an adverse effect on per capita growth rates. But the volatility of capital flows is itself endogenous, because it may arise not only from external shocks but also from domestic factors. In such conditions, modelling the sources of volatility is essential. Overall, therefore, some caution is needed in judging the robustness of the available empirical evidence on the impact of FDI on domestic investment and growth.

\section{c. Macroeconomic Effects}

The experience of the early to mid-1990s (as discussed by Fernandez-Arias and Montiel, 1996; among others) reveals that several large recipients of capital

\footnotetext{
${ }^{18}$ Haddad and Harrison also found that there is no significant relationship between higher productivity growth in domestic firms and greater foreign presence in the sector. They argue that this result may be due to the distortionary effects associated with tariff protection - foreign firms lag behind domestic firms in productivity growth in protected markets.
} 
inflows suffered from some, or a combination of some, of the potential problems identified earlier - namely, a rapid increase in liquidity, inflationary pressures, real exchange rate appreciation, and growing external imbalances. That was particularly the case in the main recipient countries in Latin America (compared to those in Asia), as a result of various factors. ${ }^{19}$ The deterioration in competitiveness weakened the credibility of the fixed exchange rate in some of these countries and raised doubts about their sustainability. There is also some evidence for sub-Saharan Africa that the liberalisation of capital inflows created macroeconomic and financial sector difficulties. Bhinda, Griffith-Jones and Martin (1999) found that increased private capital inflows contributed to real effective exchange rate appreciation in Tanzania, Uganda, Zambia and Zimbabwe during 1990-97. The domestic liquidity expansion that resulted from these inflows may also have been a factor behind the credit boom, and subsequent deterioration in banks' balance sheets, that some of these countries (most particularly Uganda) experienced during the period. Overall, the experience of the 1990s suggests that some types of policy responses (such as sterilised intervention, or a tightening of fiscal policy) can be effective in mitigating the adverse macroeconomic effects of large capital inflows in the short term; over time, however, these policies may become less effective or too costly to pursue. Sustained inflows of capital may then lead to large macroeconomic and financial imbalances (which may be compounded by a weak banking system, as noted earlier), particularly under a regime of pegged exchange rates.

\section{d. Entry of Foreign Banks}

During the 1990s, the presence of foreign-owned banks in developing and transition economies increased dramatically. As shown in Table 1, in Central Europe for instance the proportion of total bank assets controlled by foreignowned banks rose from eight per cent in 1994 to 56 per cent in 1999. In some major Latin American countries, more than half of total bank assets are now controlled by foreign institutions. ${ }^{20}$

\footnotetext{
${ }^{19}$ Chief among them were the greater reliance on pegged exchange rates in Latin America (which provide no 'cushion' when residual inflation is high); the different composition of inflows (foreign direct investment flows accounted for a larger share of inflows to Asian countries); the allocation of these flows (with a more pronounced tendency to allocate flows to investment in Asia, as opposed to consumption in Latin America); and the better ability of Asian countries to sterilise and control the money supply. As it turned out, however, these differences did not prevent a costly financial crisis in East Asia.

${ }^{20}$ It should be noted that changes in restrictions on foreign bank entry have been motivated in several countries not only by a desire to improve the levels of competition and efficiency in the banking system (as advocates of financial integration would argue) but also by the more pressing need to help reduce restructuring and recapitalisation costs of troubled domestic banks following a financial crisis.
} 
TABLE 1

Foreign Bank Ownership in Selected Emerging Markets (in per cent) ${ }^{1}$

\begin{tabular}{|c|c|c|}
\hline & $\begin{array}{l}\text { Foreign Control }^{2} \\
\text { December } 1994\end{array}$ & $\begin{array}{l}\text { Foreign Control }^{2} \\
\text { December } 1999\end{array}$ \\
\hline \multicolumn{3}{|l|}{ Central Europe } \\
\hline Czech Republic & 5.8 & 49.3 \\
\hline Hungary & 19.8 & 56.6 \\
\hline Poland & 2.1 & 52.8 \\
\hline Total & 7.8 & 52.3 \\
\hline Turkey & 2.7 & 1.7 \\
\hline \multicolumn{3}{|l|}{ Latin America } \\
\hline Argentina & 17.9 & 48.6 \\
\hline Brazil & 8.4 & 16.8 \\
\hline Chile & 16.3 & 53.6 \\
\hline Colombia & 6.2 & 17.8 \\
\hline Mexico & 1.0 & 18.8 \\
\hline Peru & 6.7 & 33.4 \\
\hline Venezuela & 0.3 & 41.9 \\
\hline Total & 7.5 & 25.0 \\
\hline Total excluding & 13.1 & 44.8 \\
\hline \multicolumn{3}{|l|}{ Brazil and Mexico } \\
\hline \multicolumn{3}{|l|}{ Asia } \\
\hline Korea & 0.8 & 4.3 \\
\hline Malaysia & 6.8 & 11.5 \\
\hline Thailand & 0.5 & 5.6 \\
\hline Total & 1.6 & 6.0 \\
\hline
\end{tabular}

Notes:

${ }^{1}$ Ownership data reflect changes up to December 1999 while balance sheet data are the most recent available in Fitch IBCA's BankScope.

${ }^{2}$ Ratio of assets of banks where foreigners own more than 50 per cent of total equity to total bank assets.

Source: IMF, World Capital Markets Report 2000 (p. 153).

From the point of view of international financial integration, two important questions that arise in this context are, as noted earlier, what impact has foreign entry had on the profitability and efficiency of domestic banks, and whether it has improved the financial system's ability to respond to large domestic and external shocks. The evidence on these issues, and more generally on the net benefits of foreign bank penetration, remains relatively limited. Claessens, Demirguc-Kunt and Huizinga (2000) studied empirically the cost and profitability effects of foreign banks, in both developed and developing countries. They used a sample consisting of bank-level data for 80 countries covering the period 1988-95, with about 7,900 individual commercial bank observations. They considered a bank to be foreign-owned if 50 per cent or more of its capital was owned by foreign residents. They found that increased penetration of foreign banks in the domestic banking system (as measured by the relative importance of foreign banks in 
either the total number of banks, or total assets, of the banking system) is associated with a reduction in both profitability and overhead costs for domestic banks. By contrast, the effect on net interest margins (that is, the ex post spread between lending and deposit rates), which can be viewed as a measure of the efficiency of financial intermediation, is not significant.

Demirgüç-Kunt and Huizinga (1999), using a similar data set, found that differences in interest margins and bank profitability reflect a variety of determinants: bank characteristics, macroeconomic conditions, explicit and implicit bank taxation, deposit insurance regulation, overall financial structure, and underlying legal and institutional indicators. A larger ratio of bank assets to gross domestic product and a lower market concentration ratio led to lower margins and profits, controlling for differences in bank activity, leverage and the macroeconomic environment. Foreign banks were found to have higher margins and profits than domestic banks in developing countries, while the opposite was observed in industrial countries. They also found that the corporate tax burden was fully passed on to bank customers, whereas higher reserve requirements were not, especially in developing countries. Overall, therefore, the evidence appears to suggest that the competitive pressures created by foreign bank entry led to improvements in banking system efficiency.

However, the fact that this conclusion holds 'on average' across a large group of countries (given the very nature of regressions with pooled, time-series crosssection data) cannot be construed as supportive evidence for any particular subset of countries or country. A particular problem with the above studies is that, in part to alleviate degrees-of-freedom problems, the authors perform their estimation in samples consisting of both industrial and developing countries. However, it is not obvious that pooling countries with very different financial characteristics is warranted; because proper statistical tests for the adequacy of pooling are not reported by the authors, one cannot conclude that their results hold for any group of developing countries - nor, for that matter, any particular country.

More focused empirical studies (at the regional or country level) are therefore needed to assess the impact of foreign bank penetration on the performance of domestic banks in developing countries. Clarke, Cull, d'Amato and Mollinari (2000), for instance, used data for the period 1995 to 1997 to analyse the impact of foreign entry on domestic banks in Argentina and found that foreign penetration increased overall efficiency in the banking sector and raised competitive pressures on domestic financial institutions. However, their analysis did not address the issue of adverse effects on credit allocation to small and medium-sized enterprises. ${ }^{21}$ Clarke, Cull and Martinez Peria (2001) using survey data for over

\footnotetext{
${ }^{21}$ Clarke et al. (2000) do note that foreign banks in Argentina have tended to concentrate their loan operations in the manufacturing sector (leaving consumer lending largely to domestic banks) but they do not address the issue of size of borrowers.
} 
4,000 enterprises in 38 developing and transition economies, did find that although large enterprises appeared to take better advantage of the presence of foreign banks, benefits also appeared to accrue to small and medium-size enterprises (SMEs). In countries with high foreign bank penetration, SMEs tended to rate interest rate costs and access to long-term loans as lesser constraints than in countries with low foreign bank entry. Medium-size enterprises also appear to finance a larger share of investment through commercial bank loans in countries with foreign bank presence. ${ }^{22}$ Nevertheless, it is difficult to make much of these results; this type of survey is notoriously unreliable, and may only offer a 'snapshot' of subjective perceptions at a given moment in time. In more recent research on Argentina, Chile, Colombia and Peru, Clarke, Cull, Martinez Peria and Sanchez (2002) found that although foreign banks do lend less to SMEs, the differential appears to be largely associated with small banks; there appears to be little difference between the share of small business lending in the portfolio of medium and large foreign-owned and domestic banks. But again, it is difficult to infer much from these results; for instance, the way the authors attempt to control for the impact of macro factors on lending shares (a time trend) is fairly crude and may result in significant bias in the econometric estimates. More rigorous quantitative research is needed to get a better understanding of this important issue.

Another issue, as noted earlier, is whether entry of foreign banks has improved the domestic financial system's ability to respond to large internal and external shocks. As noted earlier, a possible reason why domestic financial instability may increase is because foreign banks may shift funds abruptly from one market to another as the perceived risk-adjusted returns in these markets change - possibly as a result of a sudden change in expectations. To the extent that foreign banks manage their exposures to developing countries on a consolidated basis, a decision to cut exposures to an individual country could involve reductions in both cross-border lending and local operations. The evidence on this issue is very limited. In one of the few studies available, Goldberg, Dages and Kinney (2000) examined the lending behaviour of foreign and domestic banks in Argentina and Mexico in the period surrounding the 1994-95 Mexican crisis and concluded that foreign banks exhibited stronger loan growth compared to all domestic-owned banks, with lower associated volatility, and thereby contributed to greater stability in the amount of credit allocated by the overall financial system. Furthermore, they found strong similarities in the portfolio composition of lending and the volatility of lending by private foreign and domestic banks in Argentina, while

\footnotetext{
${ }^{22}$ The authors argue that the benefits perceived by SMEs may reflect, first, the lower interest margins spurred by foreign bank entry, which may help expand the amount of lending to SMEs, even if the share of lending to them declines. Second, foreign bank competition for large customers may displace some domestic banks, forcing them to more actively seek new market niches. This could potentially improve credit access for small borrowers in the medium term.
} 
the same was true in Mexico for banks with low levels of problem loans. Overall, they argued that bank health, and not ownership per se, was the critical element in the growth and volatility of bank credit.

At the same time, however, the recent experience of other countries appears to indicate that foreign banks may indeed 'cut and run' during crisis periods and may not therefore represent a stable source of domestic funding (International Monetary Fund, 2000; and Mathieson and Roldós, 2001). Thus, there does not appear to be clear support for the view that a greater foreign bank presence contributes to a more stable domestic financial system and less volatility in the availability of credit. Making strong claims in this area is, once again, premature.

Yet another issue is whether foreign banks can contribute to the stability of the domestic deposit base. Here the evidence appears to be mostly anecdotal. 'Flight to quality' was a widespread phenomenon during the Asian financial crisis, as depositors shifted funds from finance companies (at least in Thailand) and small banks toward larger banks, especially foreign financial institutions. The market share of deposits in foreign banks tripled in Korea and Indonesia between January 1997 and July 1998, while in Thailand it increased from two per cent of total deposits to five per cent in the period December 1996 to December 1997 (International Monetary Fund, 2000, p. 170). But in other recent episodes of financial instability, such as in Russia in 1998, the 'flight to quality' took the form of a switch of deposits from private banks to state banks, not foreign banks - because state-owned financial institutions were perceived to benefit from an implicit bailout guarantee from the government.

\section{A DIGRESSION ON THE TOBIN TAX}

Some economists recently revived the idea, first advanced by James Tobin in the late 1960s (see Tobin, 1978), to uniformly tax spot transactions in foreign exchange - that is, all transactions involving the conversion of one currency into another in foreign exchange markets - as a way to reduce volatility on world financial markets, and therefore mitigate the adverse short-term risks highlighted above. A key feature of the tax, according to its proponents, is that it would reduce noise from market trading while allowing traders to react to changes in economic fundamentals. It would therefore be superior to various forms of capital controls. By making currency trading more costly, it would discourage speculation - thereby reducing the volume of destabilising short-term capital flows and leading to greater stability in exchange rate and reserve movements.

An extension of the Tobin tax to a two-tier tax was also recently proposed by Spahn (1995), for countries operating flexible exchange rate or band regimes. The proposal consists in imposing a minimal-rate transaction tax (of, say, 
0.02 per cent) that would not impair market efficiency under normal market conditions, and an exchange surcharge that would be activated only in periods of heavy speculative trading - which are defined by Spahn as periods during which the trading price for a currency crosses an admissible band, consisting of $\mathrm{a}+/-x$ per cent margin around a target, the moving average exchange rate. The idea is that in periods during which the surcharge is triggered, transactions costs would rise sufficiently to cause some traders to delay transactions, thus smoothing out fluctuations in exchange rates. The surcharge is thus a variable tax on (cash) transactions in foreign exchange. The exchange rate would thus be kept within a target range through taxation rather than central bank intervention.

There are, however, several potential difficulties that may considerably limit the effectiveness of the Tobin tax and most of its variants, such as Spahn's proposal. These difficulties lie in four areas (see Garber, 1996; and Garber and Taylor, 1995): establishing the tax base, identifying taxable transactions, setting the tax rate, and implementing the tax across borders.

To limit financial market distortions, the base for any tax on international financial transactions would have to be relatively broad. However, there are strong economic arguments for exempting certain types of trades from the tax for instance, transactions made by market makers and those that increase market liquidity. In particular, trading by financial intermediaries plays generally a stabilising role. The difficulty is that in practice it is hard to distinguish, on an institutional basis, between normal trading that assures the efficiency and stability of financial markets and destabilising noise trading, which should be the only target of the tax. By reducing trading, it may paradoxically lead to less liquid markets and entail greater volatility.

Applying the Tobin tax only to spot transactions involving foreign currencies is likely to be ineffective, because market operators would eventually avoid the tax by trading in more sophisticated financial instruments such as over-thecounter derivatives. The high degree of substitutability between financial instruments may thus hamper the application of the Tobin tax. Moreover, financial derivatives such as forward transactions, futures and financial swaps allow market participants to transform long trading into short trading activities, with important repercussions on spot markets (see Garber and Lall, 1998). The volume of such transactions has grown at a very high pace over the past few years and now accounts for a significant share of all foreign exchange transactions.

Tobin's initial proposal called for a low, uniform tax rate. Given the small margins that traders realise on foreign exchange market transactions, even a 0.02 per cent tax (as proposed by Spahn) may represent a significant tax on trading activities in normal times. In addition, because some financial transactions are undertaken by several intermediaries, taxes on these transactions may have a cascading effect - implying that the effective tax rate may be significantly higher than the nominal rate applied to a single transaction. However, during periods of 
heavy speculation, even a tax of, say, three per cent on round-trip transactions (sale and repurchase of foreign currencies) is unlikely to deter speculators who expect a significant short-term change in the exchange rate (a devaluation of, say, 15 per cent). On the other hand, a tax rate that is high enough to deter speculation even in such periods would hamper the functioning of financial markets. The possible (or uncertain) benefits in terms of reducing short-term speculative trading would thus be outweighed by the possible costs associated with impairing the efficiency of financial intermediation.

Finally, the mobility of financial transactions would make the tax easy to avoid - unless it is implemented and enforced around the world (Shome and Stotsky, 1996). However, the likelihood of a universal tax can only be viewed as a remote possibility, in part because of the difficult political and economic issues that the distribution of proceeds raises. For this reason, Eichengreen, Tobin and Wyplosz (1995) favoured a more indirect means to tax foreign exchange transactions, which is a tax on lending to non-residents. This tax can be applied in one country because it applies to resident lenders. Although it would not be universal, it would reduce loans of domestic banks to foreign speculators, which constitutes an important channel of speculation.

\section{CONCLUSIONS AND POLICY LESSONS}

The purpose of this paper has been to review the analytical arguments for and against international financial integration and to examine whether the empirical evidence suggests that countries can expect (on average, at least) net benefits from it and, if so, what conditions are required to maximise them. A first issue addressed in the paper is the view that, in principle, financial openness allows countries to use international capital markets to diversify and hedge against idiosyncratic adverse shocks, particularly when those shocks are temporary. It was argued that, in practice, this alleged benefit is often a mirage for many developing countries, which often get access to these markets (if at all) only in 'good' times; as a result, the opportunities for global risk sharing and consumption smoothing are simply not there.

A related issue that was discussed in the paper is the risk of sharp reversals in short-term capital flows that may accompany a high degree of financial openness. If international capital markets are prone to over-exuberance in good times and excess pessimism or herding (leading to sudden withdrawals of capital) in bad times, the benefits of capital inflows can be completely offset by large and sudden outflows that may put an already weak domestic financial system under stress. In such conditions, financial integration may increase the risk of costly financial crises, instead of reducing them. The empirical evidence reviewed in the paper suggests indeed that international capital markets can be prone to sharp 
shifts in sentiment regarding a country's short- and longer-term economic prospects. The discipline that they exercise over government policies, although beneficial in some respects, can be excessive.

Another issue discussed in the paper is the role of entry of foreign banks. Some of the recent evidence on the effects of foreign bank penetration appears to support the view that the competitive pressures that it creates have led to improvements in the efficiency of domestic banks, and financial intermediation in general, in terms of lower operating costs and reduced net interest margins. However, whether these conclusions hold for particular sub-groups of developing countries, or individual countries for that matter, remains to be established. Moreover, there is as yet limited evidence regarding whether a greater foreign bank presence contributes to a more stable banking system and less volatility in the availability of domestic credit. In fact, the risk that foreign banks may lead to credit rationing to small firms (particularly in the non-tradables sector) and greater concentration in the allocation of credit (with adverse effects on the distribution of income) must be taken seriously. The sharp increase in foreign bank penetration observed in Eastern Europe and Latin America during the second half of the 1990s provides ample new data to analyse rigorously these issues. At this stage, however, the evidence is simply not strong enough to draw firm conclusions regarding the impact of foreign bank entry on the allocation of credit, and the strength and stability of the domestic financial system. More work - possibly along the lines of Goldberg, Dages and Kinney (2000) - is needed before broad generalisations can be made.

Nevertheless, despite creating the possibility of costly crises, and despite the fact that the existing empirical evidence does not allow blanket generalisations, global financial integration and the increase in FDI flows that it may lead to, hold potentially significant benefits in terms of higher domestic investment and economic growth rates. These 'dynamic gains' are likely to be magnified in economies where, to begin with, the stock of human capital is high enough to take advantage of complementarity effects between technology and skills. The key issue for both national and international policymakers is therefore not to choose between openness and autarky, but rather to design policies that help to minimise the short-term risks, and maximise the longer-run gains, of financial openness. From the point of view of domestic policymakers, there has been renewed emphasis on the importance of macroeconomic discipline, information disclosure, and enhanced banking sector supervision. Avoiding real exchange rate misalignment, limiting fiscal imbalances and preventing an excessive buildup of domestic debt, maintaining a monetary policy consistent with low inflation, and ensuring that the ratio of unhedged short-term foreign-currency debt over official reserves remains sufficiently low, are all preventive measures that are likely to reduce the risk that sudden changes in market sentiment may turn into large capital outflows and precipitate a financial crisis. Strengthening supervision and prudential 
regulation, and fostering risk management capacities in banks and non-financial firms, are also important. ${ }^{23}$ The stronger economic fundamentals are, the longer the track record of macroeconomic discipline, the less susceptible the country will be to potentially volatile flows, and thus the lower will be the probability of a financial crisis. ${ }^{24}$

But unwarranted changes in expectations can and do occur, even when underlying economic fundamentals appear strong. Opening the capital account unavoidably exposes countries to cycles in capital flows, particularly sharp reversals after (or during) crises. Openness also increases vulnerability to runs on the financial system. Concerns include maturity or currency mismatches, fragility of the domestic financial system, both related to excessive risk-taking encouraged by a generous (often implicit) safety net. Asymmetric information problems are likely to remain pervasive. The strengthening of the financial system (including improved supervision and accounting standards) may take a long time in countries where technical expertise in government is limited. During the transition to a more efficient financial system, distortions in domestic capital markets may continue to exacerbate the adverse effects of external volatility. For all these reasons, policymakers may need to proceed gradually with capital account liberalisation, or may have to resort to additional instruments during a transitory period, such as restrictions on short-term capital flows, to prevent excessive volatility from adversely affecting domestic stability. Without a doubt, maintaining the effectiveness of any type of restrictions on capital movements beyond the short term has proved very difficult in practice (see Ariyoshi et al., 2000; and Kaminsky and Schmukler, 2001). But even if their effectiveneness is limited to the very short run, countries may still need to consider short-term controls on capital flows as part of their arsenal of policy instruments.

Finally, it must be recognised that fostering financial integration has important implications for reforming the international financial system. Despite the heavy economics and social costs inflicted by the financial crises of the late 1990s, the world still lacks clear rules for dealing with, and preventing the occurrence of, such crises. In particular, there is neither a proper lender of last resort, nor effective standstills on unserviceable debt. How to create such mechanisms or institutions without exacerbating moral hazard remains a matter of considerable debate.

\footnotetext{
${ }^{23}$ It should be emphasised also that strengthening bank supervision and regulation prior to external financial liberalisation assumes that domestic banks are, to begin with, reasonably healthy. In countries where domestic banks are weak (in the sense of having low or negative net worth), restructuring or merging operations may be required prior to exposing them to foreign competition.

${ }^{24}$ Regional cooperation and integration can be a significant 'stepping stone' in helping countries (particularly the small ones) integrate successfully into the global trade and financial systems. The pooling of resources that the creation of a regional stock market would create, for instance, might enhance the ability of foreign investors to diversify idiosyncratic risks.
} 


\section{REFERENCES}

Agénor, P.-R. (2003), The Economics of Adjustment and Growth (2nd ed. forthcoming, Academic Press, San Diego, Cal.).

Agénor, P.-R. and J. Aizenman (1999), 'Volatility and the Welfare Costs of Financial Market Integration,' in P.-R. Agénor, M. Miller, D. Vines and A. Weber (eds.), The Asian Financial Crisis: Causes, Contagion and Consequences (Cambridge University Press).

Agosin, M. R. and R. Mayer (2000), 'Foreign Investment in Developing Countries: Does it Grow in Domestic Investment?,' Discussion Paper No. 146, United Nations Conference on Trade and Development (February).

Aitken, B. J. and A. E. Harrison (1999), 'Do Domestic Firms Benefit from Direct Foreign Investment? Evidence from Venezuela,'American Economic Review, 89 (June), 605-18.

Alba, P., A. Bhattacharya, S. Claessens, S. Ghosh and L. Hernandez (1999), 'The Role of Macroeconomic and Financial Sector Linkages in East Asia's Financial Crisis,' in P.-R. Agénor, M. Miller, D. Vines and A. Weber (eds.), Financial Crises: Contagion and Market Volatility (Cambridge University Press).

Ariyoshi, A., K. Habermeier, B. Laurens, I. Itker-Robe, J. I. Canales-Kriljenko and A. Kirilenko (2000), Capital Controls: Country Experiences with their Use and Liberalization, Occasional Paper No. 190 (International Monetary Fund, May).

Artera, C., B. Eichengreen and C. Wyplosz (2001), 'On the Growth Effects of Capital Account Liberalization,' Unpublished (University of California at Berkeley, March).

Baldwin, R. and R. Forslid (2000), 'Trade Liberalization and Endogenous Growth,' Journal of International Economics, 50 (April), 497-517.

Barro, R. J. and X. Sala-i-Martin (1995), Economic Growth (McGraw Hill, New York).

Bartolini, L. and A. H. Drazen (1997), 'Capital Account Liberalization as a Signal,' American Economic Review, 87 (March), 138-54.

Basu, A. and K. Srinivasan (2002), 'Foreign Direct Investment in Africa: Some Case Studies,' Working Paper No. 02/61 (International Monetary Fund, March).

Berthélemy, J.-C. and S. Démurger (2000), 'Foreign Direct Investment and Economic Growth: Theory and Application to China,' Review of Development Economics, 4 (June), 14055.

Bhattacharya, A., P. J. Montiel and S. Sharma (1997), 'Private Capital Inflows to Sub-Saharan Africa: An Overview of Trends and Determinants,' in Z. Iqbal and R. Kanbur (eds.), External Finance for Low-Income Countries (the World Bank, Washington DC).

Bhinda, N., S. Griffith-Jones and M. Martin (1999), 'Perception and the Causes of Flows,' in N. Bhinda, M. Martin and S. Griffith-Jones (eds.), Private Capital Flows to Africa: Perception and Reality (Forum on Debt and Development, The Hague).

Blomstrom, M., R. E. Lipsey and M. Zejan (1994), 'What Explains the Growth of Developing Countries?,' in W. J. Baumol, R. R. Nelson and E. N. Wolff (eds.), Convergence of Productivity (Oxford University Press).

Borensztein, E., J. De Gregorio and J. Wha Lee (1998), 'How Does Foreign Direct Investment Affect Economic Growth?,' Journal of International Economics, 45 (June), 115-35.

Bosworth, B. P. and S. M. Collins (2000), 'Capital Flows to Developing Economies: Implications for Saving and Investment,'Brookings Papers on Economic Activity, 1, 143-80.

Brewer, T. L. and S. D. Nollen (2000), 'Direct Investment and Portfolio Flows to Developing Countries,' Unpublished (the World Bank, March).

Caprio, G. and P. Honohan (1999), 'Restoring Banking Stability: Beyond Supervised Capital Requirements,' Journal of Economic Perspectives, 13 (Fall), 43-64.

Carkovic, M. and R. Levine (2002), 'Does Foreign Direct Investment Accelerate Economic Growth?,' Unpublished (University of Minnesota, May).

Chang, R. and A. Velasco (2000), 'Banks, Debt Maturity, and Financial Crises,' Journal of International Economics, 51 (June), 169-94.

Chuhan, P., G. Perez-Quiros and H. Popper (1996), 'International Capital Flows: Do Short-Term 
Investment and Direct Investment Differ?,' PRE Working Paper No. 1669 (the World Bank, October)

Claessens, S., A. Demirguc-Kunt and H. Huizinga (2000), 'The Role of Foreign Banks in Domestic Banking Systems,' in S. Claessens and M. Jansen (eds.), The Internationalization of Financial Services (Kluwer Books, The Hague).

Claessens, S., M. P. Dooley and A. Warner (1995), 'Portfolio Capital Flows: Hot or Cold?,' World Bank Economic Review, 9 (January), 153-74.

Clarke, G., R. Cull, L. d'Amato and A. Mollinari (2000), 'On the Kindness of Strangers? The Impact of Foreign Entry on Domestic Banks in Argentina,' in S. Claessens and M. Jansen (eds.), The Internationalization of Financial Services (Kluwer Books, The Hague).

Clarke, G., R. Cull and M. S. Martinez Peria (2001), 'Does Foreign Bank Penetration Reduce Access to Credit in Developing Countries? Evidence from Asking Borrowers,' Policy Research Working Paper No. 2716 (the World Bank, November).

Clarke, G., R. Cull, M. S. Martinez Peria and S. Sanchez (2002), 'Bank Lending to Small Businesses in Latin America: Does Bank Origin Matter?,' Policy Research Working Paper No. 2760 (the World Bank, January).

Dadush, U., D. Dasgupta and D. Ratha (2000), 'The Role of Short-term Debt in Recent Crises,' Finance and Development, 37 (December), 54-57.

Demirgüç-Kunt, A. and H. Huizinga (1999), 'Determinants of Interest Margins and Profitability: Some International Evidence,' World Bank Economic Review, 13 (May), 379-408.

Dixit, A. and R. S. Pindyck (1994), Investment under Uncertainty (Princeton University Press, Princeton, New Jersey).

Dornbusch, R., Y. C. Park and S. Claessens (2000), 'Contagion: Understanding How It Spreads,' World Bank Research Observer, 15 (August), 177-97.

Edison, H. J., R. Levine, L. Ricci and T. Slok (2002), 'International Financial Integration and Economic Growth,' Journal of International Money and Finance, 21 (November), 749-76.

Eichengreen, B. (2001), 'Capital Account Liberalization: What do the Cross-Country Studies Tell Us?,' Unpublished (University of California at Berkeley, March, forthcoming in World Bank Economic Review).

Eichengreen, B., J. Tobin and C. Wyplosz (1995), 'Two Cases for Sand in the Wheels of International Finance,' Economic Journal, 105 (January), 162-72.

Fernandez-Arias, E. and P. J. Montiel (1996), 'The Surge in Capital Inflows to Developing Countries: An Analytical Overview,' World Bank Economic Review, 10 (March), 51-77.

Garber, P. (1996), 'Issues of Enforcement and Evasion in a Tobin Tax on Foreign Exchange Transactions,' in M. U. Haq (ed.), The Tobin Tax (Oxford University Press, New York).

Garber, P. M. and S. Lall (1998), 'Derivative Products in Exchange Rate Crises,' in R. Glick (ed.), Managing Capital Flows and Exchange Rates (Cambridge University Press, Cambridge).

Garber, P. and M. P. Taylor (1995), 'Sand in the Wheels of Foreign Exchange Markets: A Skeptical Note,' Economic Journal, 105 (January), 173-80.

Goldberg, L., B. G. Dages and D. Kinney (2000), 'Foreign and Domestic Bank Participation in Emerging Markets: Lessons from Argentina and Mexico,' Working Paper No. 7714 (National Bureau of Economic Research, May).

Grossman, G. and E. Helpman (1991), Innovation and Growth in the Global Economy (MIT Press, Cambridge, Mass.).

Gruben, W. C. and D. McLeod (1998), 'Capital Flows, Savings, and Growth in the 1990s,' Quarterly Review of Economics and Finance, 38 (Autumn), 287-301.

Haddad, M. and A. Harrison (1993), 'Are the Positive Spillovers from Direct Foreign Investment?,' Journal of Development Economics, 42 (October), 51-74.

International Monetary Fund (2000), World Capital Markets Report 2000 (Ch. 4, International Monetary Fund, Washington DC).

Kaminsky, G. and S. Schmukler (2001), 'Short and Long-Run Integration: Do Capital Controls Matter?,' PRE Working Paper No. 2660 (World Bank, August).

Klein, M. and G. Olivei (2001), 'Capital Account Liberalization, Financial Depth, and Economic Growth,' Unpublished (Fletcher School of Law and Diplomacy, Tufts University, April). 
Levine, R. (1996), 'Foreign Banks, Financial Development, and Economic Growth,' in C. E. Barfield (ed.), International Financial Markets (American Enterprise Institute Press, Washington DC).

Levine, R. (2000), 'International Financial Liberalization and Economic Growth,' Unpublished (Finance Department, University of Minnesota, August, forthcoming, Review of International Economics).

Lewis, K. (1996), 'What can Explain the Apparent Lack of International Consumption Risk Sharing?' Journal of Political Economy, 106 (April), 267-97.

MacDougall, G. D. (1960), 'The Benefits and Costs of Private Investment from Abroad: A Theoretical Analysis,' Economic Record (March), 13-35.

Markusen, J. R. and A. J. Venables (1999), 'Foreign Direct Investment as a Catalyst for Industrial Development,' European Economic Review, 43 (February), 335-56.

Masson, P. R. (2000), 'Multiple Equilibria, Contagion, and the Emerging Market Crises,' in R. Glick, R. Moreno and M. M. Spiegel (eds.), Financial Crises in Emerging Markets (Cambridge University Press, Cambridge).

Mathieson, D. J. and J. Roldós (2001), 'The Role of Foreign Banks in Emerging Markets,' Unpublished (International Monetary Fund, April).

Obstfeld, M. (1994), 'Risk Taking, Global Diversification, and Growth,' American Economic Review, 84 (December), 1310-29.

Obstfeld, M. (1998), 'The Global Capital Market: Benefactor or Menace?,' Journal of Economic Perspectives, 12 (Fall), 9-30.

Obstfeld, M. (1999), 'Foreign Resource Inflows, Saving, and Growth,' in K. Schmidt-Hebbel and L. Servén (eds.), The Economics of Saving and Growth (Cambridge University Press, Cambridge).

Razin, A., E. Sadka and Y. Chi-wa (1999), 'Excessive FDI under Asymmetric Information,' Working Paper No. 7400 (National Bureau of Economic Research, October).

Sarno, L. and M. P. Taylor (1999), 'Hot Money, Accounting Labels and the Permanence of Capital Flows to Developing Countries: An Empirical Investigation,' Journal of Development Economics, 59 (August), 337-64.

Shome, P. and J. G. Stotsky (1996), 'Financial Transactions Taxes,' Tax Notes International, 12 (January), 47-56.

Spahn, P. B. (1995), 'International Financial Flows and Transactions Taxes: Survey and Options,' Working Paper No. 95/60 (International Monetary Fund, June).

Stultz, R. (1999), 'International Portfolio Flows and Securities Markets,' Working Paper No. 99-3 (Fisher College of Business, Ohio State University).

Tobin, J. (1978), ‘A Proposal for International Monetary Reform,' Cowles Foundation Discussion Paper No. 506 (Yale University, October).

Yusuf, S. (2001), 'Globalization and the Challenge for Developing Countries,' Policy Research Working Paper No. 2618 (the World Bank, June).

World Bank (2001a), Global Development Finance 2001 (the World Bank, Washington DC).

World Bank (2001b), Finance for Growth: Policy Choices in a Volatile World (the World Bank, Washington DC). 